\title{
THE ROLE OF PROBLEM SOLVING APPROACH ON STUDENT'S MATHEMATICAL CRITICAL THINKING ABILITY AND DISPOSITION
}

\author{
Asep Mulyana ${ }^{1}$, Utari Sumarmo $^{2}$, Rudi Kurniawan ${ }^{3}$ \\ ${ }^{1,2,3}$ Magister Mathematics Education of Post Graduate IKIP Siliwangi, Cimahi \\ 1 asep_mulyanaa1@yahoo.co.id, ${ }^{2}$ utari.sumarmo@gmail.com, ${ }^{3}$ krudy41@yahoo.com
}

Received: Sep 15 ${ }^{\text {th }}, 2018$; Accepted: Sep $19^{\text {th }}, 2018$

\begin{abstract}
This study was a pre test-post test experimental control group design having a goal to analyze the role of prior mathematics ability (PMA) and Problem Solving Approach (PSA) on student's mathematical critical thinking ability (MCTA) and disposition (MCTD). The study involved 65 eleventh grade students, a prior mathematics ability (PMA), a MCTA test, a MCTD scale. The study found that PMA and PSA took roles on obtaining student's MCTA and MCTD, those were the higher student's PMA the study found the higher students MCTA and MCTD. Beside that, on MCTA and its N Gain, entirely and with low and medium PMA students getting treatment with PSA attained better grades than the grades of students taught by conventional teaching (CT); and for entirely and with medium and high PMA, student recieving treatment with PSA obtained higher grades on MCTA and MCTD than student taught by CT and those grades were at good grade level. The other findings, there was no association between MCTA and MCTD, and no interaction between PAM and teaching approaches toward MCTA and on MCTD and student learn actively during PSA.
\end{abstract}

Keyword: mathematical critical thinking ability and disposition, problem solving approach

\begin{abstract}
Abstrak
Penelitian ini adalah suatu eksperimen berdisain pre test-postes dengan kelompok kontrol bertujuan menganalisis peranan kemampuan awal matematika (KAM) dan problem solving approach (PSA) terhadap kemampuan dan disposisi berpikir kritis matematik (KBKM dan DBKM). Penelitian melibatkan 63 siswa kelas-11, satu tes uraian KBKM, dan satu skala DBKM. Penelitian menemukan dalam KBKM dan peningkatannya, serta dalam DBKM siswa yang memperoleh PSA mencapai mutu yang lebih baik daripada mutu siswa yang mendapat pembelajaran konvensional (PK), dan mutu KBKM dan mutu DBKM siswa tergolong pada level baik. Siswa yang mendapat PSA hampir tidak mengalami kesulitan dalam menyelesaikan tugas-tugas KBKM sedang siswa yang mendapat pembelajaran konvensional mengalami kesulitan dalam memeriksa kebenaran proses perhitngan dan dalam membuktikan berkenaan turunan fungsi. Temuan lainnya, tidak terdapat asosiasi antara KBKM dan DBKM dan tidak terdapat interaksi antara KAM dan pembelajaran terhadap pencapaian KBKM dan DBKM. Selain itu siswa menunjukkan lebih aktif belajar selama PSA dibandingkan dalam pembelajaran konvensional.

Katakunci: kemampuan dan disposisi berpikir kritis matematik, pendekatan pemecahan masalah
\end{abstract}

How to Cite: Mulyana, A., Sumarmo, U., \& Kurniawan, R. (2018). The Role of Problem Solving Approach on Student's Mathematical Critical Thinking Ability and Disposition. JIML, 1 (3), 256-267.

\section{INTRODUCTION}

When writers observed a mathematics lesson, writers found two different impression namely, almost students could solve simple mathematics calculation problems without any difficulty. Even if, many students failed to solve complex problem and they could not identify yet the rules used in each step of the solution process. The last student's condition ilustrated that 
students less capable to solve mathematics problem critically. Whereas, mathematics curriculum (Indonesia mathematics Curriculum, 2013) attached that mathematical critical thinking ability (MCTA) was an essential mathematics learning outcomes and it should be enchanced on high school student. This was supported by Hendryawan, Yusuf, Siregar, \& Dwiyanti (2017) said students who succeeded in learning mathematics were expected to have good critical thinking skills. Beside that, some experts expressed that student should mastered MCTA, caused of as follow: a) When student thought critically, he solved problem effectively (Peter, 2012), was responsible on his opinion accompanied with logical reasoning, and did not accept information without checking its source.

Some writers explained critical thinking term in different expressions, but they included similar meaning and completed each other, such as follow, critical thinking was: a) Ability to clarify what being considered (Fisher, 2009); b) Reasonable reflective thinking based on trusted activities (Ennis, as cited in Hassoubah (2004); c) Thinking process to derive reasonable conclusion (Ennis, 1993); d) Process of deriving conclussion connected with something should be trusted and be done (Noer, 2010).

Further, as a guide for compiling instrument to assess student's MCTA, writers summerized some experts' ideas about indicators of MCTA as follow: a) MCTA contained five main activities namely: to give simple explanation, to build basic skill, to conclude, to clarify in depth and to manage strategy (Ennis, as cited in Costa(1985)); b) MCTA covered activities: to prove, to generalize, to solve problem (Glazer, 2004); c) MCTA was to determine credible resources, to differenciate relevant and unrelevant data, to identify and to evaluate unwritten asumption, happened bias, and viewpoint, to evaluate proof for supporting confession (Bayer, as cited in Hassoubah (2004)). Those indicators of MCTA ilustrated that MCTA was classified as high order thinking in mathematics and it implied for excecuting MCTA tasks student should have strong soft-skill and interest in mathematics, and strong dedication in doing mathematics task. That strong dedication attitude in doing mathematics was defined as mathematical disposition. Polking (as cited in Sumarmo (2010), Hendriana, H., Sumarmo (2014)) stated that mathematical disposition (MD) was strong desire, awareness, and dedication for thinking and doing mathematics positively. During student excecuted MCTA task well, so student should have certain mathematical disposition named mathematical critical thinking disposition (MCTD).

Mathematics Curriculum 2013, proposed that mathematical hard-skill such as MCTA and mathematical soft-skil such as MCTD should be developed simoultaneously. Moreover, Polya (1980) stated that teacher's role not only to extend mathematics content but the most important things were: to act as students, to appreciate student's thinking, to help students to think and to construct new knowledge. In other words, writers should select a kind of teaching approach that could comply with suggestion of Mathematics Curriculum 2013 and Polya's opinion for improving student's MCTA and MCTD. By reviewing activities during a lesson, writers estimated that problem solving approach (PSA) would conform to those suggestion. Some experts proposed that PSA contained some activities, namely: to understand the problem, to plan strategy, to execute the plan, and to examine process and solution. Afther writers analyzed those learning activities deeply, wirters estimated that PSA would fasilitate student to practice to identify the conformity data, to solve problem, to assess the truth of process and solution and to promote student's CDM. Those analysis supported writers' belief that PSA would take a good role on enchancing student's MCTA and MCTD 
Recently, there were limited studies analyzed MCTA and MCTD accordingly by using PSA. However, some studies examined MCTA, MCTD, and PSA variables separately. For example, Leader, L. F., \& Middleton (2004) reported PSA took a good role on promoting student's critical thinking disposition, Other example, Effendi (2017) found that student getting treatment with PSA attained better MCTA grade than the grade of student taught by conventional teaching, but there was no different grades on student's believe on mathematics.

The afforementioned arguments and findings, motivated writers to carry out a study for improving students' MCTA and CDM by using PSA and formulated research questions as follow.

1. Were MCTA grade and its normalized gain, and CDM grade of students getting treatment with PSA better than the grades of students taught by conventional teaching for entire students and based on level of student's PMA?

2. What were student's difficulties on solving MCTA tasks?

3. Was there any association between MCTA and CDM?

4. Was there any interaction between PMA and teaching approaches toward student's MCTA and toward student's CDM?

\section{Theoritical Review}

\section{Mathematical Critical Thinking Ability and Critical Disposition in Mathematics}

Mathemattical critical thinking ability (MCTA) was a basic and essential mathematics ability that should be possessed by any student who learned mathematics. There were some reason to support that statement. First, MCTA was attached in the goal of mathematics teaching among other were: MCTA exercised to think logically, sistimatically, creatively, precicely, objectively, and opened mind for facing daily live problem as well as to confront changeable future time. Secondly, when a student was thinking critically, he did not accept any information easily without detecting its source, even if he would be responsible his opinion accompanied with logical reasoning.

Some experts defined critical thinking in different expression however they enclosed similar meaning as follow: a. In general, thinking was mental process that more than just to recall and to understand but to able to relate among aspects in his memory; b. Critical thinking was reasonable reflective thinking and focussed on trusted or done determined thing. Critical thinking related to five key idea those were: practical, reflective, rational, believe, and action; c. Critical thinking was thinking involved some activities namely: to analyze, to syntheze, and to assess concepts; d. Mathematical critical thinking involved ability and disposition that combined with prior konwlegde, mathematical reasoning, and cognitive strategy for generalyzing, proving, and assessing mathematical situation reflectively.

Based on Ennis's conception (Baron, dan Sternberg, (Eds), 1987), then Sumarmo summerized indicators of MCTA as follow:a. To focus on question; $b$. To analyze and to explain question, answer, and argument; c. To consider reliable sources; $d$. To deduce and analyze duduction; d. To induce and analyze induction; e.To formulate explanation, hypothesis, and conclusion; $\mathrm{f}$. To compile meaningful consideration; and g) To interact with other people.

To consider the traits of MCTA process, it ilustrated that MCTA was a kind of high order thinking (HOT) in mathematics which it needed high mathematics soft skill for solving MCTA task. One of such mathematics soft skill was mathematical disposition (MD). Polking (as cited in Sumarmo, 2010) offered that MD was intense wish, awareness, tendency, and dedication for thinking and doing mathematics positively. Similar to Polking's opinion, 
Kilpatrick, Swafford and Findel (Hendriana, H., Sumarmo, 2014) proposed that MD was positive attitude and habit to view mathematics as logical, and useful science. Further Bandura, A., \& Wessels (1997) added that MD involved three related processess such as: self observation, self evaluation, and self reaction. Caused of student excecuted MCTA task, so student's MD was focussed on MCTA as well, that was named critical disposition in mathematics or CDM.

Refering to Polking's ideas, further Hendriana, H., Sumarmo(2014) proposed some indicators as guide for compiling instrument to assess student's CDM as follow: a) Self confidence in doing mathematical critical task, solving critical mathematics problem, giving reason mathematically, and mathematical comunicating; b) To be fexible in exploring mathematical ideas, and try to seek alternative ways in solving ciritcal mathematics problem; c) To be persistent in solving critical mathematics problem; d) To perform interest, and curiousity in doing critical mathematics tasks; e) Tending to monitor, and to reflect his own performance and reasoning; f) To assess aplication mathematics on other situation or in daily live; g) To appreciate the role of mathematics in culture, and value as a tool and as a language.

\section{Problem Solving Approach and Relevant Studies}

There were various expression to define problem solving term, even if they contained almost similar meaning. Branca (1980) and NCTM (2000) expressed that problem solving had three main meaning, as follow.

a. Problem solving as a goal. It stressed on reasoning of why problem solving should be developed on student. The main target was how to solve a problem. Such as importance of problem solving in learning mathematics it was expressed with a statement that problem solving was a general goal of learning mathematics, even it was the hart of mathematics

b. Problem solving as a process connoted a active activity included od, strategy, procedure, and heuristic for solving problem up to get a solution;

c. Problem solving as a basic skill enclosed general skill should be mastered by student in school level and skill should be possessed by student as a life skill in society. It implied that we should develop problem solving approach.

Some experts proposed meaning of problem solving approach (PSA) in almost similar as follow.

a. PSA as a lesson which stressing its activities on problem solving skill, then followed by strengthening problem solving skill;

b. PSA as a process to use strategy, way, or technique for facing a new problem so that it could be solved and reached the goal;

PSA was not directed student for collecting information as much as posible but it stressed on helping student to improve and to practice thinking ability, to solve problem and other skills so that student become self-reliant. Thus, PSA directed student's ability, willingness, feeling, enthusiasm, and thinking for solving problem and motivate student to think sistimatically.

There were variuos steps of PSA, even if they had similar phases as follow.

a. PSA enclosed four steps such as: to understand the problem, to plan strategy, to excecute the plan, and to assess the truth of solution (Polya, 1980); 
b. PSA contained five phases namely: to present problem in more clear form, to present problem in operational form, to compile hypothesis, to test hypothesis, and to assess the truth of solution (Gane as cited in Ruseffendi (2006));

c. PSA cour steps consissted of four steps those were: to understand the problem, to compile mathematical model through abstraction, to excute calculation using mathematical manipulation, and to interpret solution (Skemp as cited in Sumarmo (2010)

d. Refering to those afformentioned arguments, then Sumarmo (2010) detailed five steps in PSA such as: to realize a problem or a difficulty or confusion, to identify a problem by classifying given components and defining the goal, to use prior experience for formulating hypothesis, to test hypothesis or to seek alternative soluton, to assess solution and to conclude based on exissted evidence.

Further Polya (1980) detailed each step of PSA by posing questions as follow.

a. Understanding problem step: Was there any similar problem like this? Which theorema could be used?

b. Planning solution step: Think the problem in similar question. Did the problem need other element?

c. Carry out strategy step: To carry out the plan, to examine the truth of each step, to prove that the truth of chosen step;

d. Assessing the truth of solution step: How to test the truth of solution; Could pose its denial?; Was there other ways? Could the strategy use for other cases?

Further Jacobson, Lester, and Stengel (Sumarmo, 2010) suggested principles for improving problem solving ability such as: There was relationship between student' success in solving problem and student's experience and variety problem, there was positive relation between problem and student's interest, there was closed relationship among student, problem, and class environment.

Some benefit of PSA among other were: a. To improve student's thinking, konowlegde, and skills; b. To enchance student's attitude, curiousity, thinking objectively, ability, self reliant, critically, analitycally, either individualy or in small group; c. To help student to face problem and motivate student to attemp to mobilize whole abilities to solve the problem. Beside that, PSA possessed some advantages and disadvantages. Killen (as cited in Sukasno (2002)) offered some advantages of PSA such as: To improve meaningful answer motivate student to master deeper content; Problem solving chalenged student to obtain satisfaction in inventing a new knowlegde; Problem solving motivated student active learning; Problem solving help student to apply his knowlegde in daily live problem, to be responsible toward self learning process, to point out that mathematics was way of thinking and to improve student to think ciritically, to be self reliant and pattient. Some of disadvantages of PSA among other were: When student failed to solve problem, student believed that problem just only become busy, unwilling to try; PSA needed more time and preparation, When student work in small group, some time clever student would dominate other member; Student accustomized to recieve teacher's information would be not comfortable to learn alone; Some times student's learning style did not suitable to the demand of problem solving activity.

Recently, there were limited studies to analyze MCTA and MSC by using MPSA accordingly, but conversally there were a lot of studies involved problem solving as an ability. Some studies examined MCTA, MSC, and MPSA variables separately. For example, (Effendi, 2017) reported student getting treatment with MPSA obtained greater grades on MCTA and mathematical reasoning than the grades of student taught by conventional teaching. Beside 
that, the study did not analyzed student's MSC but mathematical disposition and did not analyzed the role of student' prior mathematics ability. Other studies reported advantages of tematic approach which oriented on open-ended mathematical problem solving than conventional teaching on improving student's mathematical divergent, critical, and creative thinking. Like that, Ramlah (2016) found that student getting treatmnet with MPSA obtained higher grades on mathematical communication and creative thinking abilities and on habits of mind than the grades of student taught by conventional teaching. Other some studies involved prior mathematics ability (PMA) and implemented various inovative mathematics teaching approaches. The studies reported that PMA took good role on improving various mathematics abilities, which ilustrated on the findings that the higher student' PMA so studies found the higher student's mathematics abilities. However, based on deeper analysis, various mathematics innovative teaching approches confered greater role than student' PMA on improving student's mathematics abilities. This statement was supported by findings that student with lower PMA and getting treatment with various teaching approaches obtained higher grades on various mathematcs abilities than the grades of student with higher PMA but taught by conventional teaching. Those findings supported statement that teacher's attempt took better role than student's PMA on enchancing student's various higher order thinking in mathematics.

\section{Method and Design of Study}

This study was a pre test-post test experimental design which having a goal to analyze the role of scienctific approach on students' mathematical critical thinking ability and mathematical self confidence. The study involved 65 eleventh grade students, an objective test of PMA, an essay MCTA test, a MCTD scale, and a perception on MPSA scale. The MCTA test consisted of 5 items, and by using Hendriana, H., Sumarmo (2014) it was obtained charactristic of MCTA test as follow: reliability test was .75; item validity were $.38 \leq \mathrm{IV} \leq .71$; discriminat power were $.31 \leq \mathrm{DP} \leq .68$, and difficulty index were $.27 \leq \mathrm{DI} \leq$ .72. In the following, we attached sample items of MCTA test, sample items of MCTD scale.

\section{Sample item of mathematical critical thinking test}

(To examine the truth of statement accompanied with explanation)

Sample Item of MCTA Test

Given a parabola equation $0=0^{2}+0$ 国 + Numbers $a, b$, and c form an aritmetics sequence. The parabola has a tangent at the point perpendicular to the line $x+6 y+2=0$. The values of $a, b$ and $\mathrm{c}$ of the parabolic equation form arithmetic series. Will be determined sketch of the satellite dish.

Write down alternative solutions with explanations and concepts!

\section{Sample item of Critical Thinking Disposition in Mathematics Scale}
Note: SA: Strongly Agree
DA: Disagree
A : Agree
SDA: Strongly Disagree

Table 1. Critical Thinking Disposition in Mathematics Scale

\begin{tabular}{|c|c|c|c|c|c|}
\hline No. & Statement & SA & $\mathbf{A}$ & $\mathbf{D A}$ & SDA \\
\hline 1. & $\begin{array}{l}\text { During a lesson, I seek information from various } \\
\text { sources. }\end{array}$ & & & & \\
\hline 2. & $\begin{array}{l}\text { When I pose a problem, I ask clarification } \\
\text { accompanied with its example and reason. }\end{array}$ & & & & \\
\hline 3. & $\begin{array}{l}\text { When I finished to solve a problem, I try to seek } \\
\text { other strategy to assess the truth of my solution. }\end{array}$ & & & & \\
\hline 4. & I accept different friend's opinion cheerfully & & & & \\
\hline 5. & I try to anayze a problem from various viewpoints. & & & & \\
\hline 6. & I used to memorize rules and procedures of & & & & \\
\hline
\end{tabular}


solving problem.

\section{Findings and Discussion}

Description of student's MCTA and MCTD were attached in Table 2.

Table 2. Student's Mathematical Critical Thinking Ability, and Mathematical Critical Thinking Disposition on Both Teaching Approaches

\begin{tabular}{|c|c|c|c|c|c|c|c|c|c|c|}
\hline \multirow[b]{2}{*}{ Variables } & \multirow[b]{2}{*}{ PMA } & \multirow[b]{2}{*}{ Stat } & \multicolumn{4}{|c|}{ Problem Solving Approach } & \multicolumn{4}{|c|}{ Conventional Teaching (ET) } \\
\hline & & & $\begin{array}{l}\text { Pre- } \\
\text { Test }\end{array}$ & $\begin{array}{c}\text { Post- } \\
\text { Test }\end{array}$ & N Gain & $\mathrm{n}$ & $\begin{array}{l}\text { Pre- } \\
\text { Test }\end{array}$ & $\begin{array}{c}\text { Post- } \\
\text { Test }\end{array}$ & N Gain & $\mathrm{n}$ \\
\hline \multirow{12}{*}{ MCTA } & \multirow{3}{*}{ High } & $\bar{X}$ & 11.56 & 37.67 & \multirow{2}{*}{.69} & \multirow{3}{*}{9} & 12.67 & 37.20 & \multirow{2}{*}{.67} & \multirow{3}{*}{10} \\
\hline & & $\%$ & 23 & 75 & & & 25 & 75 & & \\
\hline & & $\mathrm{SD}$ & 4.67 & 6.34 & .12 & & 1.51 & 3.08 & .08 & \\
\hline & \multirow{3}{*}{ Medium } & $\bar{X}$ & 11.94 & 36.76 & \multirow{2}{*}{.66} & \multirow{3}{*}{17} & 11.93 & 32.50 & \multirow{2}{*}{.54} & \multirow{3}{*}{14} \\
\hline & & $\%$ & 24 & 74 & & & 24 & 65 & & \\
\hline & & $\mathrm{SD}$ & 4.42 & 5.98 & .14 & & 4.62 & 4.70 & .10 & \\
\hline & \multirow{3}{*}{ Low } & $\bar{X}$ & 9 & 31.14 & \multirow{2}{*}{.54} & \multirow{3}{*}{7} & 9.75 & 28.38 & \multirow{2}{*}{.47} & \multirow{3}{*}{8} \\
\hline & & $\%$ & 18 & 62 & & & 20 & 57 & & \\
\hline & & SD & 2.00 & 5.67 & .12 & & 3.33 & 4.66 & .08 & \\
\hline & \multirow{3}{*}{ Total } & $\bar{X}$ & 11.21 & 35.82 & \multirow{2}{*}{.64} & \multirow{3}{*}{33} & 11.59 & 32.94 & \multirow{2}{*}{.56} & \multirow{3}{*}{32} \\
\hline & & $\%$ & 22 & 72 & & & 23 & 66 & & \\
\hline & & $\mathrm{SD}$ & 4.17 & 6.52 & .14 & & 3.81 & 5.29 & .11 & \\
\hline \multirow{12}{*}{ MCTD } & \multirow{3}{*}{ High } & $\bar{X}$ & & 102.11 & & \multirow{3}{*}{9} & & 97.40 & & \multirow{3}{*}{10} \\
\hline & & $\%$ & & 85 & & & & 81 & & \\
\hline & & SD & & 5.75 & & & & 7.68 & & \\
\hline & \multirow{3}{*}{ Medium } & $\bar{X}$ & & 98.59 & & & & 92.57 & & \\
\hline & & $\%$ & & 82 & & 17 & & 77 & & 14 \\
\hline & & SD & & 6.04 & & & & 6.05 & & \\
\hline & & $\bar{X}$ & 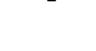 & 83 & - & & - & 84.38 & - & \\
\hline & LOW & $\%$ & & 70 & & 7 & & 70 & & 8 \\
\hline & & SD & & 6.35 & & & & 4.98 & & \\
\hline & & $\bar{X}$ & & 96.33 & & & & 92.38 & & \\
\hline & Otal & $\%$ & & 80 & & 33 & & 77 & & 32 \\
\hline & & SD & & 9.09 & & & & 7.91 & & \\
\hline
\end{tabular}

Note:

MCTA: Mathematical critical thinking ability,

MCTD: Mathematical Critical Thinking Disposition

Ideal Score: 50

Ideal Score: 120

From Table 2, in pre-test it found that there was no difference grades of MCTA of students in both teaching approaches, and the grades were at very low level. Nevertheles, after learning process, on MCTA, its gain $(\mathrm{N}-\langle\mathrm{G}\rangle)$, and on MCTD students taught by PSA either entirely or based on level of PMA (high, medium, low) attained better grades than the grades of students taught by conventional teaching. The testing hypothesis of those data (for entirely students in each class) were attached in Tabel 2. The good grade of student's MCTA in study was different with Sumarmo et.all which found that student's grade on MCTA was still at low-medium level. It might be mathematics content in Somarmo's et.all study was a difficult topic namely probabiity and trigonometry, while mathematical topic of this study was "sequence and serries". 
Further analysis, was concerning association between MCTA and MCTD. That association was analyzed by using contigency table such as in Table 4 and by using $\chi^{2}$ testing such as in Table 5. The analysis obtained value $\chi^{2}=8.290^{\mathrm{a}}$ and sig. $(2$ tailed-.082 $>.005)$. This was meant that there was no association between MCTA and MCTD.

Table 3. Testing Hypothesis of Mean Difference of Mathematical Critical Thinking Ability, And Mathematical Critical Thinking Disposition on Both Teaching Approaches

\begin{tabular}{|c|c|c|c|c|c|c|c|}
\hline Variables & $\begin{array}{l}\text { Teaching } \\
\text { Approach }\end{array}$ & ? & SD & $\mathrm{n}$ & $\begin{array}{l}\text { Sig (2- } \\
\text { tailed). }\end{array}$ & Sig (1-tailed). & Interpretation \\
\hline & PSA & 35.82 & 6.52 & 33 & .048 & $.024<.05$ & MCTA $_{P S A}>$ MCTA $_{c t}$ \\
\hline MCTA & CT & 32.94 & 5.29 & 32 & & & \\
\hline N-Gain & PSA & .64 & .56 & 33 & .000 & $.000<.05$ & $\mathrm{~N}$-Gain MCTA $_{\mathrm{SA}}>$ \\
\hline MCTA & CT & .14 & .11 & 32 & & & N-Gain MCTA $_{\mathrm{CT}}$ \\
\hline \multirow[t]{2}{*}{ MCTD } & PSA & 96.33 & 9.09 & 33 & .046 & $.023>.05$ & $\mathrm{MCTD}_{\mathrm{PSA}}>\mathrm{MCTD}_{\mathrm{ct}}$ \\
\hline & $\mathrm{CT}$ & 92.03 & 9,79 & 32 & & & \\
\hline \multicolumn{5}{|c|}{ Note: Mathematical Critical Thinking Ability } & \multicolumn{3}{|c|}{ Ideal score: 50} \\
\hline $\mathrm{Mc}$ & matical C & al Thin & Disp & & Ideal sco & e : $: 120$ & \\
\hline
\end{tabular}

Table 4. Contigency Table of Mathematical Critical Thinking Ability And Mathematical Critical Thinking Disposition in PSA Class

\begin{tabular}{ccccc}
\hline MCTA & High & Medium & Low & Total \\
\hline High & 10 & 0 & 0 & 10 \\
Medium & 10 & 7 & 1 & 18 \\
Low & 2 & 3 & 0 & 5 \\
Total & 22 & 10 & 1 & 33 \\
\hline
\end{tabular}

Table 5. Test of Pearson-Chi Square MCTA and MCTD

\begin{tabular}{ccc}
\hline Pearson- & DF & Sig.(2-tailed) \\
Chi Square $\left(\chi^{2}\right)$ & & \\
$8,290^{\mathrm{a}}$ & 4 & 0.082 \\
\hline
\end{tabular}

This findings was similar to previous study (Sumarmo, et al, 2012), that there were no association between MCTA with MCTD. This study obtained student's grade on SRL was at fairly good level. Concerning affective behavior, Sauri (2010) explained that MCTD or other affective behavior could not be taught directly such as taught a certain mathematical content. Improving better MCTD or other soft-skill in mathematics needed a long period of time, and through four ways namely: Be sure student to understand the meaning of MCTD and the important of owning MCTD in learning; Teacher should performed behavior that wished in MCTD; Familiarize students to behave the wished in MCTD; Carry out integrated and continous mathematics teaching-learning process.

Besides that, this study found that students performed more active learning in all four phases of problem solving approach (PSA) than in conventional teaching such as in the following figures (Figure 1, Figure 2, Figure 3, Figure 4). This study found that almost students' grades on MCTA were at fairly good to good level. Students realized few difficulties in solving MCTA problems. This findings was similar to Murni and Sugandi (2017) that student obtained at good grade level on MCTA. Even if, this finding was different with studies' findings with yunior high school students, among other of Koswara (2017) that students attained at low grade level on MCTA. 
264 Mulyana, Sumarmo \& Kurniawan, The Role of Problem Solving Approach on Student's Mathematical Critical Thinking Ability and Disposition

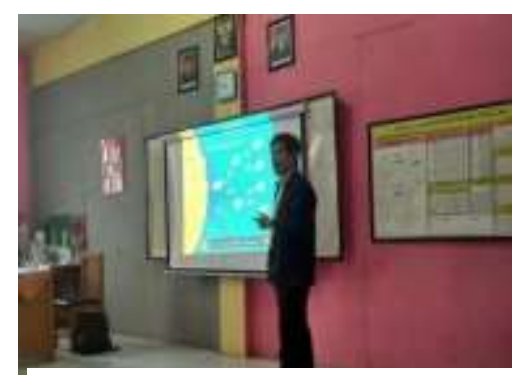

Figure 1.Teacher Presents a Contextual Problem in Phase 1

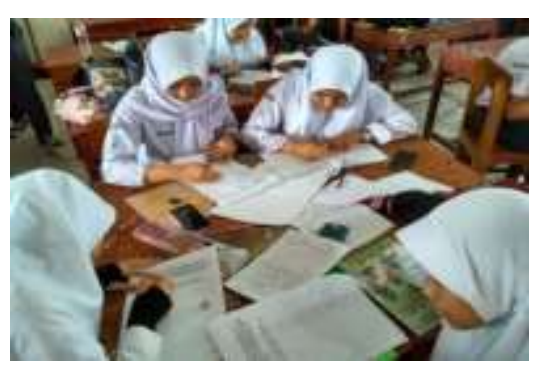

Figure 3. Students Try to Solve the Problem in Phase 3

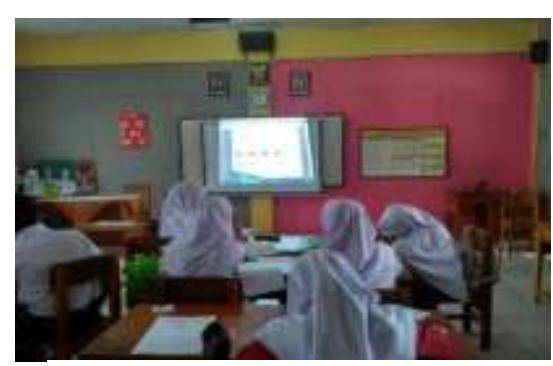

Figure 2. Students Work in Small Group to Analyze a Contextual Problem

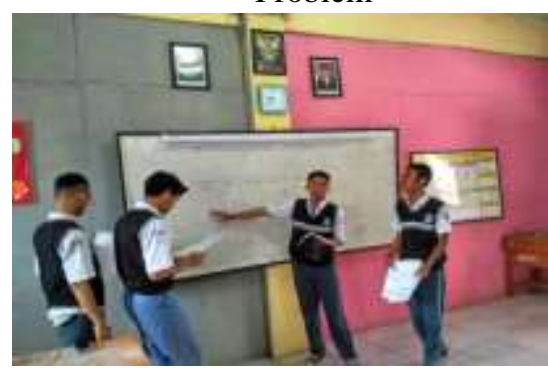

Figure 4. Students Present their Work in Front of the Class in Phase 4 Problem in Phase 1

Table 6. Mean Score of Each Item of Mathematical Critical Thinking Ability of Students in The Both Teaching Approach

\begin{tabular}{ccccccc}
\hline Teaching & Desc. Stat. & No.1 & No 2. & No.3 & No.4 & No.5 \\
approach & Ideal score & 8 & 8 & 10 & 12 & 12 \\
\hline \multirow{3}{*}{ PSA } & ? & 5.64 & 5.78 & 7.03 & 9.22 & 8.46 \\
& \% of ideal score & 70.50 & 72.25 & 70.30 & 76.80 & 70.50 \\
CT & ? & 5.62 & 5.63 & 6.52 & 7.98 & 6.36 \\
& \% of ideal score & 70.30 & 70.50 & 65.20 & 77.30 & 50.4 \\
\hline
\end{tabular}

Further analysis was about interaction between PMA and teaching approaches (PSA and conventional teaching) toward student's MCTA and MCTD. The analysisi was using twopath Anova (Table 5) and Diagram (Figure 5 and Figure 6). Based on Table 5, it obtained sig .464 $>$.005. It meant that there was no interaction between PAM adan teaching approache (PSA and conventional teaching) toward student's MCTA and MCTD. This finding was also ilustrated on Diagram interaction (Figure 5), that pointed out the lines didnot intercept.

Table 6.Two-way Anova Test MCTA Based on Learning Methods and PMA

\begin{tabular}{lcrrrr}
\hline Source & $\begin{array}{c}\text { Type III Sum of } \\
\text { Squares }\end{array}$ & Df & Mean Square & \multicolumn{1}{c}{ F } & \multicolumn{1}{l}{ Sig. } \\
\hline Corrected Model & $684.709^{\mathrm{a}}$ & 5 & 136.942 & 5.041 & .001 \\
Intercept & 68075.547 & 1 & 68075.547 & 2505.758 & .000 \\
Metode & 92.312 & 1 & 92.312 & 3.398 & .048 \\
KAM & 497.310 & 2 & 248.655 & 9.153 & .000 \\
Metode * KAM & 42.264 & 2 & 21.132 & .778 & .464 \\
Error & 1602.891 & 59 & 27.168 & & \\
Total & 79206.000 & 65 & & & \\
Corrected Total & 2287.600 & 64 & & & \\
a. R Squared =.299 (Adjusted R Squared $=.240)$ & & & \\
\hline
\end{tabular}




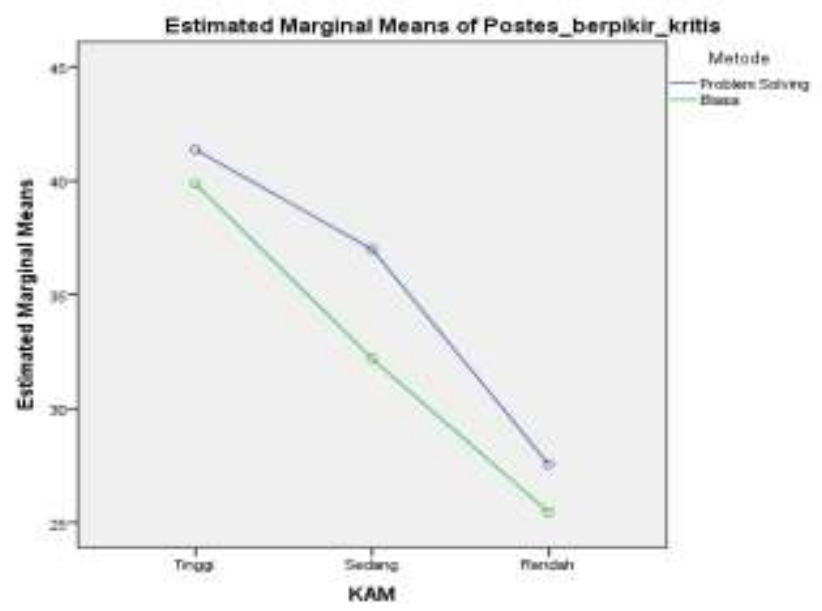

Figure 5. Interaction Between Learning Methods and PMA on MCTA

Table 7. Two-way ANOVA Test MCTA based on learning methods and PMA

\begin{tabular}{lcrrrr}
\hline Ource & $\begin{array}{c}\text { Type III Sum of } \\
\text { Squares }\end{array}$ & Df & Mean Square & F & Sig. \\
\hline Corrected Model & $2614.560^{\mathrm{a}}$ & 5 & 522.912 & 13.589 & .000 \\
Intercept & 511955.310 & 1 & 511955.310 & 13303.840 & .000 \\
Metode & 157.049 & 1 & 157.049 & 4.081 & .048 \\
KAM & 2226.407 & 2 & 1113.204 & 28.928 & .000 \\
Metode * KAM & 124.958 & 2 & 62.479 & 1.624 & .206 \\
Error & 2270.424 & 59 & 38.482 & & \\
Total & 581860.000 & 65 & & & \\
Corrected Total & 4884.985 & 64 & & & \\
a. R Squared $=.535$ (Adjusted R Squared $=.496)$ & & & \\
\hline
\end{tabular}

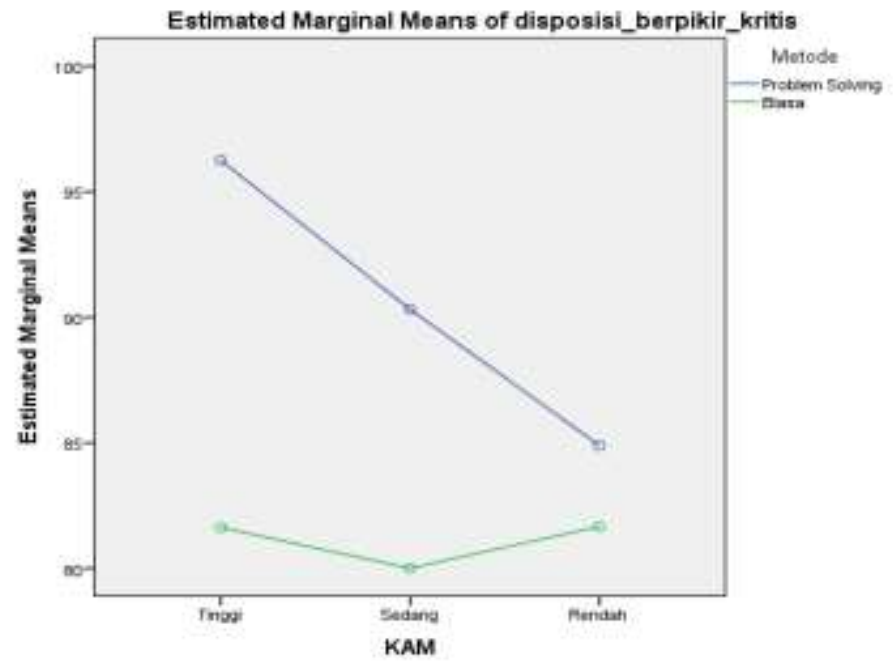

Figure 6. Interaction Between Learning Methods and PAM Against MCTD

\section{CONCLUSION DAN SUGGESTION}

\section{Conclusion}

Based on findings and discussion, the study derived conclusion as follow.

The problem solving approach and previous mathematical ability took better role than conventional teaching on improving students' mathematical critical thinking ability and its gain, and on mathematical critical thing disposition. The students' mathematical critical 
thinking ability and mathematical critical thinikng disposition grades were at fairly good level. Students on both teaching approaches realized few difficulties in solving mathematical critical thinking ability problems.

The other conclusion were that, students peformed more active learning in all four phases of problem solving approach, there was no association between mathematical critical thinking ability and mathematical critical thinking disposition, there was no interaction between previous mathematical abilitin

\section{Suggestion}

Based on the conclusion and discussion the study proposed some suggestion as follow.

The students' grade on mathematical critical thinking ability and in mathematical critical disposition in both classes were at fairly good level. Mathematical critical thinking was classified as high order thinking (HOT) in mathematics. For obtaining HOT ability such as mathematical critical thinking abilty, firstly students should master prerequisite of mathematical process and content of mathematical critical thinking ability. So, before teacher were going to explain a new mathematics topic or content or to conduct study on mathematical HOT ability, it was suggested to examine students' abilities of its prerequisite firstly. Besides that, students should be motivated to select and to solve more exercises by theirselfes on mathematical HOT ability and or on mathematical critical thinking ability. In order students attained meaningfull mathematical critical thinking ability, it was suggested students asked to write the formulas and rules which used on each step in solving the problems as well.

To improve better students' mathematical critical thinking disposition, it was suggested four ways as follow: Be aware of students to the importance of having mathematical critical thinking disposition; teacher should perform having behavior as wished in mathematical critical thinking disposition; students should be accustomized having behavior as wished in critical thinking disposition; teacher should carry out integrated and continous mathematics teaching process.

\section{REFERENCES}

Bandura, A., \& Wessels, S. (1997). Self-efficacy. W.H. Freeman \& Company.

Branca, N. A. (1980). Problem solving as a goal, process, and basic skill. Problem solving in school mathematics, 1, 3-8.

Costa, A. L. (1985). Developing Minds. A resource Book for Teaching Thinking Association for Supervision and Curriculum Development. Virginia: Alexandria.

Effendi, A. (2017). Meningkatkan Kemampuan Berpikir Kritis dan Penalaran Matematis serta Belief Siswa SMP dengan Menggunakan Pendekatan Pemecahan Masalah. Bandung: Unpublished Thesis at Post Graduate Study of STKIP Siliwangi.No Title.

Ennis, R. H. (1993). Critical thinking assessment. Theory into practice, 32(3), 179-186.

Fisher, A. (2009). Berpikir Kritis: Sebuah Pengantar. Jakarta: Erlangga.

Glazer, E. (2004). Technology Enhanced Learning Environment that are Conductive of Critical Thinking in Mathematics.[online]. Tersedia: http://www.lonestar.texas.net/scifert/crit2.html 6 Desember 2009.

Hassoubah, Z. I. (2004). Developing Creative and Critical Thinking Skills. Bandung: Yayasan Nuansa Cendikia.

Hendriana, H., Sumarmo, U. (2014). Penilaian Pembelajaran Matematika. Bandung: Refika Aditama.

Hendryawan, S., Yusuf, Y., Siregar, I., \& Dwiyanti, W. (2017). PEMBELAJARAN 


\section{BERBASIS MASALAH DENGAN GREEN' S MOTIVATIONAL STRATEGIES U NTUK MENINGKATKAN KEMAMPUAN BERPIKIR KRITIS MATEMATIKA SISWA SMP, 29-40.}

Leader, L. F., \& Middleton, J. A. (2004). Promoting critical-thinking dispositions by using problem solving in middle school mathematics. RMLE Online, 28(1), 1-13.

NCTM. (2000). Principles and Standards for School Mathematics. USA: NCTM.

Noer, S. H. (2010). Peningkatan Kemampuan Berpikir Kritis, Kreatif, Dan Reflektif (K2R) Matematik Siswa SMP Melalui Pembelajaran Berbasis Masalah. Bandung: Unpublished Disertaion at Postgraduate UPI.

Peter, E. E. (2012). Critical Thinking: Essence for Teaching Mathematics and Mathematics Problem Solving Skills. African Journal of Mathematics and Computer Science Research, 5(93), 39-43.

Polya, G. (1980). On Solving Mathematical Problems in High School. New Jersey: Princeton Univercity Press.

Ramlah. (2016). Meningkatkan Kemampuan Komunikasi dan Berpikir Kreatif Matematis serta Kebiasaan Berpikir Siswa MTS Melalui Pendekatan Problem Solving. Bandung: Unpublished Thesis at Post Graduate Study of STKIP Siliwangi.

Ruseffendi. (2006). Pengantar Kepada Membantu Guru Mengembangan Kompetensinya dalam Pengajaran Matematia untuk Meningkatkan CBSA.

Sukasno. (2002). Model Pembelajaran Pemecahan Masalah dalam Pembelajaran Trigonometri. Bandung: Tesis pada PPS-UPI.

Sumarmo, U. (2010). Berpikir dan Disposisi Matematik: Apa, Mengapa, dan Bagaimana Dikembangkan pada Peserta Didik”. [Online]. in http://www.docstoc.com/docs/ 62326333/Pembelajaran-Matematika. [5 Maret 2012]. Paper published in Sumarmo, U. (2013) and Suryadi, D. Turmudi, Nurl. Bandung: Jurusan Pendidikan Matematika FPMIPA UPI.No Title. 